\title{
Protean Uses of Trust: A Curious Case of Science Hoaxes ${ }^{1}$
}

\begin{abstract}
This article explores an intervention that practises the 'art of deception' in the context of biomedical publishing. Specifically, we explore the science hoax aimed at revealing problems in the peer review process. We pose a question - are science hoaxes based on deception ever justified? Drawing on interviews with biomedical scientists in the UK, we identify the issue of trust as the key element in the scientists' evaluations of hoaxes. Hoaxes are seen by some to increase trust, and are seen by others to damage trust. Trust in science is thus a Protean concept: it can be used to argue for two completely different, and sometimes contradictory, positions. In this case, the same argument of trust was recognizably invoked to defend the hoaxes, and to argue against them.
\end{abstract}

Keywords: peer review, science hoax, trust in science.

\section{Różne aspekty zaufania: dziwny przypadek mistyfikacji naukowych}

\begin{abstract}
Abstrakt
Niniejszy artykuł opisuje projekt, w którym skorzystano ze „sztuki oszustwa” w kontekście publikacji biomedycznych. Badamy mistyfikację naukową mającą na celu ujawnienie problemów w procesie recenzji. Stawiamy pytanie: czy mistyfikacje naukowe oparte na podstępach mogą być uzasadnione? Korzystając z wywiadów z brytyjskimi naukowcami z dziedzin biomedycznych, zidentyfikowaliśmy zagadnienie zaufania jako kluczowy element w ocenie mistyfikacji przez naukowców. Misty-

\footnotetext{
* Adam Smith Business School, University of Glasgow.

** University of Dundee.

1 This paper is based on the study Trust in science: Managing overflow in science funded by the British Academy (MD150056).
} 
fikacje postrzegane są przez jednych jako zwiększające zaufanie, a przez innych jako je naruszające. A zatem zaufanie jest $w$ nauce koncepcją zmienną: można je wykorzystać do obrony dwóch zupełnie różnych, a czasem nawet przeciwnych stanowisk. W tym przypadku argument zaufania został wykorzystany do obrony mistyfikacji i do wysunięcia argumentów przeciwko nim.

Słowa kluczowe: proces recenzji, mistyfikacja naukowa, zaufanie do nauki.

\section{Introduction}

This paper explores an intervention that practises the 'art of deception' in the context of biomedical publishing. Specifically, the intervention we are exploring is the science hoax, at the heart of which lies a spoof scientific paper that so artfully creates its deception that it goes unnoticed and undetected.

We pose a question - are science hoaxes based on deception ever justified? Our interest in science hoaxes is embedded in a broader discussion about the peer review system, in particular whether or not it is a reliable tool in determining the quality of science communication. The so-called 'peer review crisis' is a multifaceted crisis that has deepened over time, taking on added urgency with new developments in biomedical publishing.

Peer review in science communication has been defined by Ware (2013: 6) as "the process of subjecting an author's scholarly manuscript to the scrutiny of others who are experts in the same field". At its most basic, the peer review process seeks to establish whether the science in the paper is rigorous and trustworthy. In addition to its discriminating and screening function by way of quality control, peer review also confers legitimacy on the science in the paper, and creates value for authors. Most studies on the relevance and suitability of peer review suggest that scientists support peer review, in principle, as the best available way of assessing quality; however, they also identify numerous problems with how it is practised (House of Commons Science and Technology Committee 2011; Wellcome Trust 2013; Fyfe 2015), though some damning evaluations can be found (Eisen 2011)

Problems with peer review have been discussed for decades. In 1988 Richard Smith bemoaned possible biases against certain individuals, lack of consensus, bias against innovative science, excessive costs and delays. These issues have hardly changed in the years since. The lack of suitable, willing reviewers is an issue of concern for journal editors (Siebert et al. 2015), because of increasing workloads and the unpaid nature of the system. This creates challenges to the sustainability of peer review, not least given the amount of time scientists need to perform this task.

Scientists and commentators have expressed concerns about inadequate training and support for reviewers (Wellcome Trust 2013), conscious or unconscious bias, sloppy reviews, undeclared conflict of interest and reliance on flawed or too narrow indicators (Miller 2006; Lee et al. 2013). Commentators have also observed 
exaggerated praise, conservatism in assessment related to homophily (Lamont 2009; Ioannidis 2011) and lack of consistency in assessments (Südhof 2016). The question who is a 'peer' in peer review is not that easy to answer. Is it someone who does research in the same area? Or someone who is equal in rank and experience with the person whose work is assessed? If it is a friend of the author, there is the risk of favourable treatment, and if it is a competitor, there is the risk of exaggerated criticism (Smith 2006).

The literature also mentions the risk to the reputation of the journals if peer review procedures fail to identify problems with manuscripts and they proceed to publish flawed research (Wellcome Trust 2013). These risks directly relate to the subject of our paper, i.e. science hoaxes aimed at spotting and ridiculing flaws in peer review. In our paper, we pose some questions regarding the merit of hoaxes. We discuss examples of science hoaxes, evaluating the rationale for them that was provided by their authors. Specifically, we focus on Bohannon's hoax, conducted with support from Science, because it speaks to the most recent concerns that contribute to the peer review crisis, as well as foreshadowing the changing nature of the science hoax - the role it is set to play beyond a one-off intervention by alternatively being referred to as a sting. In discussing Bohannon's hoax, we explain how Bohannon implemented the hoax and what other results it yielded, based upon reactions and perceptions among scientists. We then outline the methodology of our study, after which we proceed to the analysis of our data. Finally, we place the discussion of hoaxes in the context of trust in science.

\section{The science hoax}

The tradition of hoaxes can be found in Greek mythology. The Greek god Hermes delighted in mischief by outwitting other gods, either for his amusement or for the good of humankind. Another mythic trickster, Prometheus, in an act of cunning, deception and rebellion, tricked Zeus and secured a feast for men who had been destined as a sacrifice to the gods.

Walsh (2006), in her book, Sins Against Science, relates the roots of the word hoax to the phrase 'hocus pocus' and in her investigation she distinguishes it from satire and parody. Although there is a humorous side to a hoax, it is more like a practical joke and typically has a victim, the butt of the joke. Furthermore, according to Walsh, a successful hoax, unlike satire and parody, must be believable, and for it to be believable it must play into the expectations of the reader, of popular media in her cases, while also working with certain expectations about how the text will be read. For a hoax to be successful, it is the expectations of the reader that are eventually betrayed, and the deception becomes obvious. Thus, unlike satire and parody and while playing for laughs, hoaxes place trust at stake: trust in the text being the real thing, and trust in the truthfulness of what is being communicated. 
Contemporary examples of hoaxes include the artistic practice of a group of popular culture pranksters called the Yes Men, who, rather than speak truth to power, somewhat mischievously impersonate power and adopt and perform what they refer to as 'corrective identities' (Boler 2006). Their hoaxes aim to call attention to corporate and governmental misconduct, falling short on social responsibility and accountability. Another example is the artist-trickster and postcolonial cultural theorist, Coco Fusco, who also used impersonation in her performances. Most melodramatically, she pretended to be dead (Better yet when dead) in a performance piece exploring the theory that women, particularly artists, in Latin America, do not exercise control over their bodies, unless they die spectacular deaths at a young age, at which point they capture the popular imagination and become celebrated.

Hoaxes and tricksters can also be found among literary authors. Mark Twain and Edgar Allan Poe engaged in science hoaxes at the time when the public was "keen to believe anything that came stamped with the imprint of 'science"' (Walsh 2006: 30). According to Walsh, authors like Twain and Poe exploited this keenness, against "the mounting social power of science" (2006: 31), 'humiliating' the audience for their keenness.

Given the element of betrayal, which is not present in satire and parody, the hoax is not what it pretends to be. Therein lies the art of the deception: to create a deception so perfect that it goes unrecognized (Gabriel 2004). A hoax is designed to trick people by being so uncannily like the original that it goes undetected as fake, except under close scrutiny. A good peer review is supposed to perform this close inspection, distinguishing not only between good and bad science, but also between real and fake science. The deception goes unnoticed until the hoax is revealed, and the veil is pulled back. The spoof paper is the deception that goes unnoticed, a fake that would make a con-artist proud. But whereas artists and storytellers have always had artistic license to deceive and lie, scientists did not normally have such license until, it could be argued, Alan Sokal (1996), a professor of physics, set a precedent.

Sokal's hoax involved the publication of his article, "Transgressing the boundaries: towards a transformative hermeneutics of quantum gravity" in the journal "Social Text" (1996), which at the time was not peer reviewed. His actions were referred to as a Trojan horse attack (Baringer 2001) in the context of the so-called science wars (Turner 2003; Stolzenberg 2004) that raged when postmodernism and poststructuralism were at their height. The editors of Social Text accepted it for publication as a serious contribution to the social and cultural critique of science and scientific 'dogma', their agenda for the journal at the time set, as summarized by Sokal (1996) in his interpretation, against the 'existence of an external world' and in favour of the dismissal of 'objective' procedures and epistemological strictures prescribed by the scientific method. Sokal argued that such a critique proliferated 'nonsense and sloppy thinking', which his hoax, that is the acceptance of his 
paper, was aimed to demonstrate, as it epitomized such thinking. He furthermore added that dismissing the existence and importance of 'facts and evidence', part of Social Text's critique of scientific dogma, as he interpreted it, prevented journals like "Social Text" from questioning important social realities such as "how corporate and government funding influence scientific work', an even more pressing concern today.

When asked about the ethics of his hoax, as a standard against which to evaluate its merits, Sokal stated that he did not practise deception, because the content of the article was publicly available for verification. Thus, shying away from its association with deception, he referred to his actions as a satire or parody instead, aimed not only at 'postmodernism', but also at the editors who failed to identify the paper as fake. Except that he also wanted the editors to believe it was a real paper, on which the success of his hoax depended. The moment of truth that he sought was disclosing their failure in doing their duty as scholars, accepting poor and biased thinking instead, as demonstrated by accepting his paper. As Sokal (1996) stated: "The editors' duty as scholars is to judge the validity and interest of ideas, without regard for their provenance. (That is why so many scholarly articles practise blind refereeing)".

In 2013 the prestigious journal "Science", together with journalist and scientist John Bohannon, faked a research paper. The spoof paper was then sent to 304 open access journals. The intention behind presenting reviewers with a spoof paper was to catch poor peer review in the act, 'incompetence' on the part of editors and reviewers involved in open-access publishing, to demonstrate poor quality control, thus turning the tables against them as purveyors of competent science. The acceptance, or failure to reject, was the moment of truth: a sign that they had taken the bait, as Bohannon refers to it, and failed to perform competent, discerning quality control. Of the 304 open access journals, 255 went through the entire process, to acceptance or rejection, but $60 \%$ showed no signs of peer review, meaning the editor made the decision. Of the 106 papers that demonstrated signs of peer review, $70 \%$ accepted the paper.

Bohannon (2013) reported on his actions in his article, "Who is afraid of peer review"? At the start of the article, Bohannon stated that the paper he submitted, or the bait, should only have been faced with rejection because "any reviewer with more than a high-school knowledge of chemistry and the ability to understand a basic data plot should have spotted the paper's short-comings immediately. Its experiments are so hopelessly flawed that the results are meaningless".

For it to succeed and to be taken seriously as real, nevertheless, the paper had to be "fatally flawed" yet "credible", which depended on successfully playing into expectations about what a real science paper looks like and how it reads. To this end, Bohannon consulted two independent groups of molecular biologists at Harvard University. They helped him 'fine-tune' the scientific flaws so that the paper and the science would be both obvious and "boringly bad" (Bohannon 2013), 
staging a waning of interest on the part of the reviewers, thus potentially undermining the kind of close reading on which quality control depends, whether one is knowledgeable or not. Earlier drafts were possibly too "interesting", for being weird, and potentially offered a glimmer of hope in terms of pointing towards or promising a breakthrough. The biologists also told him to change the language if he wanted it to be convincing, because it read like a piece written by a native speaker of English, not the non-native English speaker from an African country who was supposedly the author. He situated the papers' authors in Africa, making up their names by taking random names from online databases, also randomly adding middle initials, while for the institutions he combined Swahili words and African names and generic institutional words and African capital cities. He reasoned it would arouse less suspicion if nothing about them could be found on the Internet. In the end, he generated several near identical papers, seemingly single-authored, which would be somewhat suspicious for the biomedical sciences.

The paper itself was concerned with a cure for cancer that is a "simple test of whether cancer cells grow more slowly in a test tube when treated with increasing concentrations of a molecule". A "second experiment" saw the cells treated with "increasing doses of radiation to stimulate cancer radiotherapy". The conclusion stated that "the molecule is a powerful inhibitor of cancer cell growth" and it "increases the sensitivity of cancer cells to radiotherapy". Bohannon said that are "numerous red flags in the papers", with "the most obvious in the first data plot": while the caption of a graph claims one thing, the data shows the opposite. In addition, only a "glance" at the 'Materials \& Methods' section "reveals the obvious explanation for this outlandish result". The second experiment, according to Bohannon, was even more outrageous and it would be "impossible to conclude anything from it". And if the scientific errors would not have been enough to reject the paper, "its apparent advocacy of bypassing clinical trials certainly should be".

Bohannon's hoax is not the only one aimed at the peer review process. In 1998, with the Internet not as prominent as it is today as a promising venue for publication and providing different challenges for the peer review process, Fiona Godlee, the editor of the "British Medical Journal" (BMJ), concocted an article containing eight deliberate mistakes in various aspects of the study - design, the analysis of data and interpretation. She sent the fake article to over 200 of the regular reviewers of the BMJ and her findings exposed serious flaws in the peer review system (Godlee et al. 1998). None of the reviewers spotted all the mistakes, while some did not spot any.

In 2009, Philip Davis, a graduate student from Cornell University, also created a hoax to test the editorial standards of Bentham Science Publishers. Davis, with colleague Kent Anderson, who was at the time a member of the publishing team at the New England Journal of Medicine, created an incomprehensible computergenerated paper. One of Bentham Science Publishers' journals, The Open Information Science Journal, failed to spot that the paper was a fake. Davis then revealed 
the hoax and withdrew the paper. The editor-in-chief of the journal took full responsibility for the mistake and resigned (Shepherd, "The Guardian" 2009).

The tradition of science hoaxes continues, not only testing peer review but also other editorial processes. Most recently, four Polish scientists - Sorokowski, Kulczycki, Sorokowska and Pisanski (2017) - created a fictitious scientist, Anna 0. Szust, complete with fake accounts for her on Academia.edu, Google+, Twitter and a faculty webpage. On behalf of the fictitious scientist they applied to the editorial boards of 360 journals, a mixture of JCR-listed journals with impact factors and those from the 'Beall's List' (Beall 2015) and the DOAJ (Directory of Open Access Journals). Four journals immediately appointed Szust as Editor-in-Chief, 40 predatory and 8 DOAJ journals appointed her as an editor, while all JCR-listed journals either failed to respond or rejected her.

\section{Research design}

Our interest in science hoaxes emerged when we conducted a larger project on 'trust in science'. Drawing on the relevant literature on this topic, for this project we explored the following themes: trust and distrust among scientists, the importance of personal and laboratory reputations, integrity and competence in science, the present prescriptions of scientific rigour, and the appropriateness of the peer review system.

We interviewed 28 scientists in the UK, including (1) senior scientists in management positions of laboratory head or research team leader; (2) junior scientists with less than five years' experience of working in scientific labs; and (3) journal editors from the area of biomedical sciences responsible for managing the peer review system.

During the interviews, we specifically asked for their knowledge of science hoaxes and we elicited their evaluations of the outcomes of these hoaxes. We were interested in the ethical judgements by scientists: did they consider science hoaxes morally justified? We also asked about the impact science hoaxes have on science: did they improve or hinder scientific pursuit?

The analysis followed abductive reasoning. At the beginning of the analysis we coded the transcripts of the interviews with a view to identifying the ways in which scientists responded to science hoaxes. Following the recommendations of Miles and Huberman (1994), we engaged in repeated readings of the material - moving back and forth between our data and the literature, until we were satisfied that we had identified a usable classification.

In analyzing the data, we identified value judgements, which we classified as supportive of hoaxes, critical of hoaxes, or 'the shades of grey' in between. This third category included various forms of qualifying the judgement, i.e. hoaxes were seen as justified in certain circumstances, but not justified in others. 


\section{Findings}

As occurs with many phenomena studied by social scientists, the perceptions and appreciation of science hoaxes varied in terms of whether or not they improve or hinder science, why and how, in the context of the peer review system. Rather than being dichotomous, the perceptions could be placed on a continuum with some voices in favour, some voices against, and a range of views in between, in various ways qualifying, evaluating, weighing and making the case for or against hoaxes on balance.

Some scientists were in favour of hoaxes, because in their view they reveal the flaws in the peer review system in a way that other methods are unable to do, while also drawing attention to the occurrence of another form of faking it, namely corruption, which some suspect to be more widespread. In the spirit of the hoax, one journal editor forcefully called for more such tests:

Any schemes like that will show up where things are going wrong. I think I'd like much more of it, and I'd like much more social science investigation of corrupt practices in science. I mean I've been talking about this and writing about this for years.

For scientists like this, the means justify the end, i.e. even though the hoax is based on deception, its use is justified as it reveals problems which cannot be exposed to the same effect by other methods. Simply asking the reviewers if they conduct reviews properly would not yield credible findings, basically because, as another scientist suggests, people cannot be trusted on their word:

How else would you do it without [the hoax]. If you just go and ask [reviewers or editors] how is [the system] working well, they're obviously going to say yes, because if they say no, they're devaluing their journal.

There was a group of scientists, however, who saw merit in hoaxes, but warned against repeating them. For example, these two scientists showed frustration with new attempts to devise more and more innovative hoaxes:

I would never do it myself and I think maybe it's been done enough times to show that there are issues with peer review.

It's an interesting experiment to do once. They probably should have let the journals know it was a hoax a little bit sooner, before some of the journals published the paper, which, my gosh, scares me. It should have been stopped before it went that far. Now that hoax paper is actually in the scientific literature because once a paper's published, it's published. People can retract papers but they're not really retracted, they're still out there. I certainly think that it's a one-time experiment, I don't think you should ever do it again. 
For some scientists there are acceptable and unacceptable hoaxes and what differentiates these is whether the spoof paper is ultimately published. If the paper is published, then the hoax erodes trust in science as a system, as it completely invalidates scientists' work.

One scientist saw the value in testing the system, but felt that hoaxes can damage the external reputation of science and scientists, which carried more weight in adding up to the disapproval of hoaxes, because at the end of the day, reputable science not only enjoys favourable public opinion, but also gets funded:

They're actually not bad tests of the system because it does go to show how some reviewers really don't take the peer review seriously, but I do also think it can be damaging to science, because the results of that kind of test of the system do become public, and it can't help but cause people to think that we are wasting our money giving scientists work when they're not even taking it seriously.

Similarly, another scientist saw the hoaxes as sensationalistic journalism undermining trust of the public in science:

The downside is that it can lead people in the public to think 'oh science publishing is just an absolute mess, right, all journals are just completely dysfunctional'. If you don't actually understand the full landscape of publishing... so I guess I'm not, I'm not enthusiastic about it because I haven't seen it result in anything other than somewhat sensationalistic journalism and then not much else.

Viewed as sensationalism, hoaxes were seen to be eroding trust in science as a system, not so much trust among scientists but the general public's trust in science, which is often funded by taxpayers. Thus, while the headlines are shortlived, the damage it does to trust, undermining it, is much more long-lasting and potentially erosive, especially when hoaxes keep being repeated, a concern of some scientist in their perception and appreciation of hoaxes.

Also drawing on the erosion of trust were the scientists who are firmly against hoaxes. For them hoaxes waste editors' and reviewers' time, and destroy their goodwill. One scientist, who was also a journal editor, firmly condemned hoaxes because they abuse trust in the truthfulness of 'the exercise' one is being asked to perform, with precious resources going to waste along the way, resources that help sustain the scientific community together with trust, such as voluntarism:

I would feel as though my time and goodwill was wasted. (...) I would be angry. There's never enough time to do everything and when I do say that I'm reviewing a paper, I do take it seriously. So if I found out that it was a pointless exercise, I would feel a bit angry and I might possibly never review for that journal again. 
It was noticeable that when hoaxes were mentioned, some scientists immediately referred to the problems of poor science due to online publishing, and not to problems of poor science in good journals:

There's an absolute problem in the ease with which one can create journals now that you don't have to print them and you can do everything online, it's become an easy way of making money, I fear, and there are people at the periphery of science whose careers are improved by publishing papers. It doesn't matter where they are or what they say, and I would love some way of squashing that. I don't think it's a reflection of peer review. (...) I think there's a lot of very poor science out there and it's much easier to do that now and probably, you know, the sort of quite clear distinction between the scientific literature and the non-scientific literature is in danger of disappearing because of the ease of making these online journals.

Whether this stance is motivated by a desire to defend the canon of good journals, many scientists argued that 'something like this', being tricked into publishing fake science, would not happen in 'a good journal'. One scientist argued: "It's interesting that the paper would get published (...) in lower journals, yes, but in higher journals it's not likely". Others referred to the so-called predatory journals (Beall 2015) that prey on the desperate need to get published: "These predatory journals that are seemingly really about money and will publish anything".

One journal editor also called attention to such predatory journals, and the threat they pose, as imposters:

I kind of shrug my shoulders, to be blunt with you. Look at our editorial board, and there's a Who's Who of people because they're all friends of mine and I know them very well. Then you get a lot of weird and wonderful predatory journals, basically they're almost scams, it is scamming really (...) what they're trying to do is fleece research institutions of money and researchers of money by setting themselves up as being bona fide when they're not.

Another editor firmly denied that a hoax would ever occur in their journal because of 'the right checks' in the prepublication process:

I think it's good and we have never received anything like this, and if we will receive a fake paper with the level of checking that we do, we can detect it easily. Our number of publications per month is not very high.

Some expressed disbelief that any 'respectable scientist' would fall for a hoax:

I'm surprised at that (...) Who did they ask to review it? It might just be that they're not doing their reviewing properly. Or have they actually got the right people to review it, so they've maybe asked the wrong type of scientists, or someone in the wrong field... 
When explicitly asked about alternatives to peer review, few interviewees advocated change to the current system, which resonates with recent literature (House of Commons Science and Technology Committee 2011; Wellcome Trust 2013), and only some discussed modifications. These modifications may improve the system and as such will make hoaxes aimed at poor review redundant. There is still potential for abuse of the review system in terms of getting fraudulent science published, although some alternatives simultaneously take aim at this problem. For example, one editor saw data transparency as the future of science publishing, which in their view has the potential to improve the peer review process and trustworthiness of publications by doing away with trust as the operating principle for reviewing; if everything is visible and verifiable, one does not have to take and trust anyone's word for it being genuine:

Now if you take a paper and in science, you have a lot of data, a lot of graphs, and most of this can be totally fabricated. You don't know whether these experiments were actually done. (...) This is why now Nature and all these journals ask you to submit all the original data to the website so people can look at it. In the past, you could publish a paper that could be completely fabricated, nowadays at least you have to provide the raw data. This doesn't imply that the raw data are necessarily correct but putting the original data is helping to avoid this problem of reproducibility.

When you take something like [name of a cancer science journal], for example, they pay very high rates for very high quality biostatistical reviews because we know that if you just get a raft of epidemiologists to look at your paper or biostatisticians they often won't spot the cardinal mistakes. (...) I've had this discussion with a lot of editors I think we're making a major mistake in our journals as they stand at the moment in not paying for what I call the hard indepth quantitative analysis that's required for peer review.

Another editor advocated paying for reviews, as opposed to relying on voluntarism, professionalizing the process further, and specializing peers to refer to experts exclusively, which in their view would make the peer review less vulnerable to bad practice and hoaxes:

\section{Discussion}

So, is deception in science ever justified? Do the science hoaxes we investigated improve or damage science? Does the end of exposing weaknesses in the peer review process justify the means of deceiving scientists along the way? Our interviewees provided positive and negative evaluations, and a range of evaluations which fell 'in the middle' of the two dichotomous positions. Some of these median 
explanations evoked the notion of casuistry, i.e. they were based on the logic that circumstances alter cases (Jonsen and Toulmin 1988; Toulmin 2001). Casuistry in moral philosophy carries a tinge of scepticism towards generalization in normative matters. Indeed, Toulmin (2001) has emphasized the degree to which case-based arguments share their power with the rich circumstantial detail of a justification.

Interestingly, when asked about science hoaxes, our interviewees expressed concerns not about deception itself, but about its impact on trust. It is perhaps unsurprising, given that trust is said to sustain the fabric of the scientific community, as well as driving support for science in society (Brown 2001; Kitcher 2001; Longino 2002; Vinck 2009; Stone and Jasny 2013).

On the one hand, some scientists hoped that the use of hoaxes may help repair trust in science, as they believe that once flaws in the system have been made apparent, improvements will be made. Such improvements will go towards mending trust externally, of the general public in science, and internally, within the community of scientists. So, although the authors of hoaxes rarely put forward remedies for the ills of the system, improvements will happen. Indeed, hoaxes sometimes achieve such a desired effect. For example, the editors of "Social Text", the journal which fell victim to the Sokal hoax, subsequently amended and improved the journal's publishing practices and became more responsible members of the academic community.

On the other hand, however, trust was seen a casualty of hoaxes. Firstly, because hoaxes may generate scandalous headlines and ridicule scientists, further damaging the public's trust in science. Secondly, hoaxes are seen to damage trust among scientists, who suspect that they may fall victim to someone's joke, consequently experiencing embarrassment and losing face. Wasting reviewers' time is a loss of a valuable resource, especially when the hoax is more than a one-off experiment to prove a point.

Zen Faulkes, in his collection of hoaxes, Stinging the predators: a collection of papers that should not have been published, comments on hoax fatigue, referring to it as "YASP syndrome (Yet Another Sting Paper)". However, beyond tiring scholars, the repeated use of hoaxes may pose a significant threat to trust by running the risk of becoming a tool to police science and scientists, one to be used stealthily. The term 'sting' places hoaxes in the realm of undercover operations conducted by law enforcement and secret services, undercover or secret 'police'. A sting catches someone in the act of doing something wrong, and accuses the person in question, which goes further than embarrassing them, as with the cruel humour of a hoax. It is more ethically questionable than a hoax as it involves entrapment. Furthermore, to label a hoax a sting speaks to a particular imagination, and offers a particular narrative of being on the side of 'the law', good guys, rather than being on the side of 'the criminals', bad guys. Indeed, Science describes the landscape of open-access publishing as 'the Wild West', as if there are no good guys to be found, only bad guys, or predators. 
It should be remembered that embarrassment is an integral part of a hoax (Walsh 2006). Embarrassment and shame presuppose a community, insofar as one is embarrassed and ashamed in the eyes of other people who matter (Goffman 1959). Thus, science hoaxes can be funny, but like pranks, they can also be cruel, as they have a victim. The victim may be the journal editors, the reviewer or the publisher. In the case of the Phillip Davis hoax referred to above, the victim, the Editor-in-Chief of "The Open Information Science Journal", resigned from his post (Shepherd 2009).

In addition, by focusing on 'bad apples' hoaxes may tar 'good' and 'bad' science with the same brush, especially when the reporting, blogging and debate on hoaxes runs the risk of not making carefully informed distinctions that make it clear, for instance that open-access publishing is not the problem necessarily, but those exploiting its growing pains, namely predatory journals that practice poor peer review. In the face of uncertainty, some scientists prefer to sustain the status quo, and choose to trust the existing journals as being the 'good' journals.

Thus, both the arguments in favour of hoaxes and those against them hinge on the notion of trust. Hoaxes are seen by some to increase trust, and are seen by others to damage trust. A closer look at science hoaxes throws a different light on trust as a Protean concept: it can be used to argue two completely different, and sometimes contradictory, positions. In this case trust was recognizably invoked to defend the hoaxes, and to argue against them.

\section{References}

Baringer P. S. (2001) Introduction: The "science wars" in: After the science wars: science and the study of science, K. Ashman \& P. S. Baringer (eds.), New York, Routledge: $1-13$.

Beall J. (2015) Predatory journals and the breakdown of research cultures, "Information Development", 31 (5): 473-476.

Bohannon J. (2013) Who is afraid of peer review? "Science", 342 (6154): 60-65, http://science.sciencemag.org/content/342/6154/60.full

Broad W. \& Wade N. (1982) Betrayers of the truth, London, Century Publishing.

Brown J. R. (2001) Who Rules in Science? An Opinionated Guide to the Wars, Cambridge, MA: Harvard University Press.

Collins H., Evans R. and Weinel M. (2017) STS as science or politics?, "Social Studies of Science", 40 (2): 307-340.

Faulkes Z. (2017) Stinging the predators: a collection of papers that should never have 
been published, https://figshare.com/articles/Stinging_the_Predators_A_collection_ of_papers_that_should_ne ver_have_been_published/5248264

Eisen M. (2011) Peer review is $f^{* * *} e d$ up-let's fix it, http://www.michaeleisen.org/ $\mathrm{blog} / ? \mathrm{p}=694$

Fyfe A. (2015) Peer review not as old as you might think, Times Higher Education, June 25, https://www.timeshighereducation.com/features/peer-review-not-old-you-mightthink

Gabriel Y. (2004) The narrative veil: truth and untruths in storytelling in: Myth, stories and organizations. Premodern narratives for our times, Y. Gabriel (ed.), Oxford: Oxford University Press: 17-31.

Godlee F., Gale C. R., Martyn C. N. (1998) Effect on the quality of peer review of blinding reviewers and asking them to sign their reports: a randomized controlled trial, "Journal of American Medical Associations", 280: 237-240.

Goffman E. (1959) The Presentation of Self in Everyday Life, Penguin.

House of Commons Science and Technology Committee (2011) Peer review in scientific publications, London, The Stationery Office Limited, https://publications. parliament.uk/pa/cm201012/cmselect/cmsctech/856/856.pdf

Ioannidis J. P. A. (2011) More time for research: Fund people not projects, "Nature", 477: 529-531.

Jonsen A. and Toulmin S. (1988) The Abuse of Casuistry, Berkeley, California, California University Press.

Kitcher P. (2001) Science, Truth, and Democracy, New York \& Oxford, Oxford University Press.

Lamont M. (2009) How Professors Think: Inside the Curious World of Academic Judgement, Cambridge, Mass. Harvard University Press.

Lee C. J., Sugimoto C. R., Zhang G., Cronin B. (2013) Bias in peer review, "Journal of the American Society for Information Science and Technology", 64 (1): 2-17.

Longino H. (2002) Science \& the common good: thoughts Philip Kitcher's Science, Truth \& Democracy, "Philosophy of Science", 59: 560-568.

Miles M. B. and Huberman A. M. (1994) Qualitative Data Analysis, London, Sage.

Miller C. (2006) Peer review in the organization and management sciences; Prevalence and effects of reviewer hostility, bias, and dissensus "Academy of Management Journal", 49 (3): 425-431. 
Shepherd J. (2009) Editor quits after journal accepts bogus science article, "The Guardian", https://www.theguardian.com/education/2009/jun/18/science-editor-resignshoax-article

Siebert S., Machesky L. and Insall R. (2015) 'Overflow in science and its implications for trust', "eLife" 4: e10825.

Smith R. (1988) Problems with peer review and alternatives, "British Medical Journal", 298: 774-777.

Smith R. (2006) Peer review: a flawed process at the heart of science and journals, "Journal of the Royal Society of Medicine", 99 (4): 178-182.

Sokal A. (1996) A physicist experiments with Cultural Studies, "Lingua Franca", May/June.

Sorokowski P., Kulczycki E., Sorokowska A., and Pisanski K. (2017) Predatory journals recruit a fake editor, "Nature", Mar 22; 543 (7646): 481-483. doi: 10.1038/543481a.

Südhof T. C. (2016) Truth in Science publishing: A personal perspective, "PLOS Biology", http://journals.plos.org/plosbiology/article?id=10.1371/journal.pbio.1002547

Stolzenberg G. (2004) Kinder, Gentler Science Wars, "Social Studies of Science", 34 (1): 115-132.

Stone R. \& Jasny B. (2013) Scientific discourse, Buckling at the seams. Introduction to Special Issue. Communication in Science: Pressures \& Predators, "Science", 342 (6154), 56-57, http://science.sciencemag.org/content/342/6154/56

Toulmin S. (2001) Return to Reason, Cambridge, Mass., Harvard UP.

Turner S. (2003) Third science war, "Social Studies of Science", 33, 4: 581-611.

Vinck D. (2010) The sociology of scientific work. The fundamental relationship between Science and Society, Cheltenham, Edward Elgar Publishing Ltd.

Walsh L. (2006) Sins against science: The scientific media hoaxes of Poe, Twain, and others, Albany, State University of New York Press.

Ware M. (2013) Peer Review: An Introduction and Guide, Publishing Research Consortium, http://publishingresearchconsortium.com/index.php/prc-guides-main-menu/ 155-peer-review- an-introduction-and-guide

Wellcome Trust (2015) Scholarly Communication and Peer Review: The Current Landscape and Future Trends, https://wellcome.ac.uk/sites/default/files/scholarlycommunication-and-peer-review- mar15.pdf 